\title{
Author Correction: Rapid and efficient induction of functional astrocytes from human pluripotent stem cells
}

Isaac Canals (D), Aurélie Ginisty, Ella Quist DD, Raissa Timmerman, Jonas Fritze (D), Giedre Miskinyte, Emanuela Monni, Marita G. Hansen, Isabel Hidalgo, David Bryder, Johan Bengzon and Henrik Ahlenius (D)

Correction to: Nature Methods https://doi.org/10.1038/s41592-018-0103-2, published online 20 August 2018

In the version of Supplementary Fig. 1 originally published with this paper, some images in panel e were accidental duplicates of images in panel b. This error has been corrected in the online integrated supplementary information and in the Supplementary Information PDF.

Published online: 4 December 2018

https://doi.org/10.1038/s41592-018-0264-z 